\title{
Wojna polsko-rosyjska (1609-1618) w staroruskiej literaturze historycznej
}

Urszula Wójcicka 


\section{Urszula Wójcicka}

\section{Wojna polsko-rosyjska (1609-1618) w staroruskiej literaturze historycznej}

$\mathrm{J}$ edną z wielu cech literatury staroruskiej wyciskających piętno na jej wewnętrznej strukturze

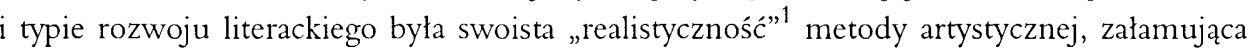
powszechne w tej literaturze dążenie do zachowania kanonu i podporządkowania formy etykiecie. Staroruska „realistyczność”, naruszająca jednolity system norm wielostylowego piśmiennictwa dawnej Rusi, jawiła się nie jako przeciwieństwo kanonu literackiego czy odrzucenie umowności i abstrakcyjności sztuki, ale jako oryginalne ich uzupełnienie i ukonkretnienie. Wynikała ona z wnikliwej obserwacji zdarzeń, prowadzącej do stworzenia iluzji rzeczywistości przez zmianę sposobu przedstawiania świata: przybliżenie środków wyrazu do przedstawianego tematu. Próbę stworzenia takiej właśnie iluzji rzeczywistości łatwo odnaleźć w artystycznym ukazywaniu wydarzeń wojny polsko-rosyjskiej lat 1609-1618 w zabytkach XVII-wiecznej literatury historycznej: Nowvej opowieści o przestawnym carstwie rosyjskim, Placzu o niewoli i calkowitym zniszczeniu państwa rosyjskiego, Pskowskiej opowieści kronikarskiej o czasach Smuty, Opowieści Abrahama Palicyna o oblężeniu klasztoru Troicko-Sergijewskiego ${ }^{2} \mathrm{i}$ innych.

Zaproponowane tu określenie „literatura historyczna”, w odniesieniu do piśmiennictwa, którego zasadniczą właściwością był historyzm średniowiecznego typu, traktować należy umownie, jako nazwę

\footnotetext{
1 Termin „realistycznośc” przcjmuję za Dymitrem Lichaczowem, który używał go w celu przeciwstawienia „realizmowi" współczesncj literatury, by podkrcślić odrębność składników dawnej metody artystyczncj od istnicjących znaczcń słowa „realizm”. Zob. Д. С. Лихачев, Поэтика древнерусской литературь, Москва 1979, podrozdz. Элементы реалистицности, s. 129-160. Por. też polski przckład: D. S. Lichaczow, Poetyka literatury staroruskiej, tł. A. Prus-Bogusławski, Warszawa 1981, s. 126-159.

2 Wszystkic wymicnione tu utwory opublikowano w tomic: Памиятники литературы Древней Руси. Конеч XVI-начало XVII веков, Москва 1987; сytaty podaje w przckładzie własnym, oznaczone dalej: NO — Nowa opowieśé o przesławnym carstwie rosyjskim; PN - Płacz o niewoli i calkowitym zniszczeniu państwa rosyjskicgo; PO Pskowska opowieśc kronikarska o czasach Smuty; OP _ Opouieść Abrahama Palicyna o oblężeniu klasztoru Troicko-Sergijeu'skiego (w nawiasach paginacja).
} 
zbiorczą obejmującą teksty o różnej przynależności gatunkowej ${ }^{3}$, ale jednolitej tematyce, związanej z konkretną epoką i wiedzą o niej w określonym czasie. Występujące w takich utworach elementy „realistyczności” służyły wspólnemu celowi - uwiarygodnieniu relacji o autentycznych wydarzeniach. Przyczyniały się w ten sposób do nadania wyrazistości autorskiemu przesłaniu, którego funkcja było najczęściej uświadamianie potrzeby zmiany rzeczywistości. Tę zmianę w pierwszym ćwierćwieczu XVII wieku wymuszała niestabilna sytuacja polityczna Rosji, spowodowana walkami o władzę w okresie tzw. Smuty oraz zbrojną interwencją wojsk polskich, podjętą za panowania Zygmunta III w imię utopijnego marzenia o opanowaniu całej Rosji i zakończoną kapitulacją wojsk polskich.

Żaden z XVII-wiecznych utworów staroruskich nie był dokumentarnym zapisem ani szczegółową opowieścią o przebiegu działań wojennych. Każdy, przedstawiając charakterystyczny epizod i wyrażając jeden punkt widzenia, uzupełniał wcześniejszą relację i tworzył z nią zamkniętą całość. Relacjonując wydarzenia wojny polsko-rosyjskiej, nieznani w większości twórcy wykorzystywali zarówno tradycyjny „kanon sytuacji”, utrwalony przez gatunek opowieści wojennej, jak też naruszające ów kanon elementy „realistyczności”. Daje się zauważyć, że kanoniczne „formuły wojenne” wykorzystywano do wykreowania takiej sytuacji fabularnej, jaka była konieczna $z$ punktu widzenia wymagań etykiety literackiej, a więc w opisie wroga, jego zachowań i postępków, a także opisie krzywd ciemiężonego przez interwentów narodu rosyjskiego oraz w wezwaniach do sprzeciwu wobec najeźdźcy.

Oddziały polskie przedstawiane były za pomocą stałych epitetów odsłaniających istotę działań każdego wroga w każdym czasie, w rodzaju: „rozwścieczone wojsko biesowskie” („бесояростное воинъство”, PN, 138), „, bezduszne wilki” („душапагубныя волки”, NO, 36), „przeklęci i bezbożnicy” („окаянники и безбожники”, NO, 28), „gnębiciele i krwiopijcy niewinnej krwi” („губители и кровопролители... кровей”, NO, 38) i tak dalej. W identyczny sposób charakteryzowano i oceniano poczynania przeciwników. Zygmunt III był w zabytkach staroruskich najczęściej „przeklętym królem” („окаянный король”, NO, 31, 40), „bezecnym królem” („нечестивый король”, „злочестивый король”, PN, 140), „okrutnym wrogiem” („лютый враг”, NO, 26; „лютый супостат”, NO, 34), „rabusiem wiary prawosławnej” („,nохититель веры...православныл", NO, 34), „sprawcq̨ zguby wielu dusz i złym oprawcą wielkiego państwa” („многодуиный губитель и зльй разоритель великаго государства”, NO, 42). Zwykle upodabniano go do szatana żądającego od swych poddanych-biesów ciągle nowej ofiary, postępującego jak wąż (NO, 38), skorpion (NO, 40), wściekły pies (NO, 42) czy „nienasycony krwiopijca” (PN, 42). Podobnie zachowywali się jego żołnierze — „bezduszne biesowskie zastępy” (NO, 40) o „przepełnionych intrygami i złością sercach” (NO, 26), którzy ,jak złe wilki”

\footnotetext{
${ }^{3}$ Jednoznaczne określenie przynależności gatunkowej utworów staroruskich jest niekiedy bardzo trudne albo wręcz niemożliwe. Wynika to nic tylko z wahań samego autora co do wyboru określenia gatunkowego (np. „historia”, „opowieść, „słowo”) czy wprowadzenia nazw gatunków niezbyt wyraźnie różniących się między sobą (np. „spowiedź”, „wyznanie”; „latopis”, „kronika”), ale z powszechnej tendencji do łączenia w jednym utworze kilku gatunków (np. „opowiadanie i widzenie”, „opowiadanie i posłanie”, „żywot i opowieść”). Podstawą do wyodrçbnicnia gatunku były nie tyle literackie właściwości zabytku, ile temat bądź przedmiot narracji, któremu dany utwór był poświęcony. Zwykle określenia gatunkowe łączyły się z określeniem przedmiotu narracji.
} 
i „lute lwy” równali z ziemią miasta, porywali i „pochłaniali” mieszkańców. „Rozwścieczony złością i biesowską zuchwałością" hetman Żółkiewski „przelał wiele krwi chrześcijańskiej” (PN, 140); „syn ciemności” (OP, 168), „heretyk” (OP, 214), „luteranin” (OP, 222), „zły złodziej i rozbójnik pan Lisowski (...) spustoszył Ziemię Nowogrodzką i zajął Psków” (PO, 154); „przeklęty” (OP, 240) „bezbożnik” (OP, 212) hetman Sapieha ${ }^{4}$ bezskutecznie oblegał klasztor Troicko-Sergijewski.

Tradycyjnymi formułami i literackimi „kanonami sytuacji”, przenoszonymi z utworu do utworu na zasadzie loci communes, posługiwano się również w celu zobrazowania następstw wrogiego najazdu. WXVII-wiecznych zabytkach staroruskich taki stereotypowy opis krzywd poczynionych przez polskiego interwenta sprowadzał się najczęściej do uogólnionego stwierdzenia o ucisku, w rodzaju: „i wszelkie wielkie prześladowania [ludzie - U. W.] cierpią” (NO, 24), „i niezliczone nieszczęścia na nią [Rosję - U. W.] spadły" (PN, 138), albo do emocjonalnie zabarwionego wyliczania różnych form przemocy, na przykład:

Nieustannie wielu [ludziom grozi — U. W.] śmiertelne posiekanie, innym ciężkie zranienie, jeszcze innym okradzenie, a niewiastom zniesławienie i pohańbienie

$$
\text { (NO, 48); }
$$

I wiele grodów i wsi spustoszyli, i święte wielkie Ławry zburzyli, i nierozkładające się i czczone ciała świętych (...) z grobowców wyrzucili i skazali na zbezczeszczenie

$$
\text { (PN, 138); }
$$

I przelali jak wodę krew niewinnych, i trupy umarłych pokryły ziemię. (...) a z tych, co uciekli z ich rąk i tak wielu na drogach skonało od mrozu, głodu i wszelkiej udręki

$$
\text { (PN, 144). }
$$

Tego typu etykietalne przedstawienia zachowań wrogów, pełniące w dawnych tekstach funkcję artystycznego uogólnienia, w zabytkach XVII-wiecznych o wiele częściej niż w utworach wcześniejszych nasycane były elementami „realistyczności”. Składały się na nie charakterystyczne szczegóły i artystyczne detale właściwe tylko dla danej sytuacji albo konkretne zdarzenia pozwalające odtwarzać rzeczywistość już nie w umownych formach, ale w sposób maksymalnie zbliżony do samej rzeczywistości. W agitującej za zbrojnym wystąpieniem przeciwko Zygmuntowi III Nowej opowieści o przestawnym carstwie rosyjskim, przedstawiającej wydarzenia z przełomu lat 1610-1611, „urealistycznienie” przekazu dokonywało się poprzez wprowadzenie do uniwersalnego opisu, informacji o jednostkowych zdarzeniach. Na przykład umownie przedstawianą grabież uwiarygodniało stwierdzenie o „odbieraniu przemocą cudzej własności”, zilustrowane następnie zachowaniem prześladowców, którzy nie kupowali towaru zgodnie z jego wartością, ale zaniżali ceny, nie płacili

\footnotetext{
4 Są to w zasadzie jedyne pejoratywne określenia Sapichy. W przeciwicństwie do pozostałych dowódców „charakteryzowanych" za pomocą najbardziej wyszukanych epitetów o zabarwieniu negatywnym, zwłaszcza Lisowskiego, z którym Sapieha współdziałał podczas oblężenia klasztoru Troicko-Sergijewskiego, nazywano go po prostu „hetmanem Sapiehą". Można przypuszczać, że w ten sposób okazywano mu mniejszą pogardę niż innym interwentom.
} 
srebrem, tylko wymuszali bronią i groźbą śmierci (NO, 48). Fakt odbierania przez nich domów potwierdzała gorzka refleksja o bezkarności i nadmiernym bogaceniu się, jako że „nie w swoje posiadłości przyszli i ponad miarę wszelką pozyskać chcą" (NO, 38).

Inne nieetyczne postępki interwentów, jak utrudnianie codziennego życia ludności, odzieranie z godności, brak szacunku dla uczuć religijnych, wyrażane zwykle stereotypowym uogólnieniem, w rodzaju: „cóż jeszcze więcej mogli wymyślić, jak by tu nas, prawosławnych chrześcijan, ciemiężyć, poniewierać, wyszydzać, wyśmiewać" (NO, 48), ukonkretniały w Nowej opowieści... faktyczne zdarzenia odnotowane w późniejszych dokumentach źródłowych. Ulokowane w konkretnym miejscu i konkretnym czasie eliminowały one umowność z etykietalnej formuły i urealniały przekazywaną informację. W takiej właśnie ukonkretniającej funkcji występował epizod z wrotami kremlowskimi zamkniętymi dla mieszkańców Moskwy z rozkazu hetmana Gosiewskiego. Wpółotwartego przejścia, jedynego w grodzie połączenia z centrum handlowym, pilnowali z obydwu stron uzbrojeni piesi i konni strażnicy wymuszający porządek strachem. I chociaż liczba mieszkańców - jak zauważa autor - znacznie zmniejszyła się, to i tak przedostanie się ciasnym korytarzem nie było latwe:

zawsze u wrót tych [ludzie - U. W.] zaczynali na siebie napierać i jak myszy cisnąć się, i była wrzawa, piski i krzyki z powodu wąskiego i utrudnionego przejścia i przejazdu

$(\mathrm{NO}, 48)$.

Identyczną rolę pełnił przywołany przez autora epizod z obciętymi rękoma, przybitymi do ściany pod ikoną Bogurodzicy w kremlowskiej cerkwi. Ręce polskiego szlachcica Blińskiego, ukaranego przez Gosiewskiego, faktycznego zarządcę pozbawionej władzy Moskwy, za strzelanie do świętego obrazu po wybuchu gwałtownych zamieszek w mieście, stanowić miały przestrogę dla najeźdźców, żądnych podobnych świętokradczych czynów. W Nowej opowieści... konkretyzowały one zarzut o obrazę uczuć religijnych Rosjan. Z kolei w Ptaczu o niewoli i catkowitym zniszczenit panstwa rosyjskiego w takiej samej funkcji wykorzystano fakt zbezczeszczenia grobu moskiewskiego cudotwórcy, błogosławionego obłąkanego Wasyla. „Realistyczność” przekazu wzmacniały tu informacje o rozrąbaniu na części grobowca świętego, wyrzuceniu jego trumny i wybudowaniu w miejscu złożenia ciała stajni z przegrodami dla koni. Zasygnalizowane elementy „realistyczności”, sprzyjające zanikowi średniowiecznej idealizacji wydarzeń, wywoływać miały u czytelników niechęć do interwentów i zachęcać do walki z nimi.

Konstruktywną rolę w tworzeniu XVII-wiecznej iluzji rzeczywistości odegrały w omawianych utworach metafory typu realistycznego, oparte na bezpośredniej obserwacji zjawisk i wychwytywaniu tego, co dawało się naocznie zaobserwować. Na przykład broniący się przez dwadzieścia miesięcy Smoleńsk, który odmówił poddania się 20-tysięcznej armii Zygmunta III, nie podporządkował się postanowieniom moskiewskiej Dumy Bojarskiej („семибоярицны”) i w rezultacie - jako jedyny spośród grodów rosyjskich - kontynuował opór wobec interwentów, stając się dla współczesnych symbolem męstwa, upodobniony został do „nieustraszonego 
żołnierza” powściągającego za uzdę „dzikiego, drapieżnego i nieposkromionego źrebaka”. Całą wściekłość źrebaka — polskiego najeźdźcy — żołnierz przyjmował na siebie:

...i ciało jego [źrebaka - U. W.] do siebie przyciaga i władzy jemu nad sobą nie daje, bo jeśli da, to sam od niego zginie, poniesiony zostanie w przepaść bezdenną i rozbije się

$(\mathrm{NO}, 34)$.

Również podbita przez wojska polskie Rosja przedstawiana była metaforycznie jako wdowa po zmarłych bezpotomnie Rurykowiczach, a jednocześnie „piękna i szlachetna, bogata i powszechnie znana, we wszystkim doskonała narzeczona" $(\mathrm{NO}, 30)^{5}$, z którą - wbrew jej woli - swatał się „przeklęty król” Zygmunt III:

Z powodu odmowy narzeczonej, jej krewnych i ludzi życzliwych nie może on jednak w krótkim czasie wziąć jej i mężem jej zostać, dopóki krewnych i życzliwych narzeczonej siłą i jakimiś podstępami nie pokona i sobie nie podporządkuje, a wtedy i narzeczoną z całym jej bogactwem za siebie weźmie

$$
\text { ( } N O, 30) \text {. }
$$

Nowego pretendenta na tron rosyjski, którym wedle układu zawartego w 1610 roku pod Smoleńskiem miał zostać syn Zygmunta III — królewicz Władysław Waza, nieznany z imienia twórca, zwolennik wspólnych rządów przyszłego cara i Dumy Bojarskiej, utożsamiał z gałęzią oderwaną od zgniłego, gorzkiego i krzywego pnia, która — posadzona na wysokim i sławnym miejscu, starannie podlewana i użyźniana Duchem Świętym i nakazem Stwórcy - mogłaby z czasem przemienić się w potężne drzewo, całkowicie odmienione, karmiące ludzi słodkimi owocami (NO, 28).

„Realistyczność” podobnych metafor nadawała przedstawianym faktom szczególną wyrazistość, przekształcała jednostkowe sytuacje w zdarzenia ponadindywidualne, charakterystyczne dla określonej epoki.

Obok tradycyjnej w dawnych tekstach religijnej interpretacji zdarzeń i objaśniania przyczyn nieszczęść karą Bożą za grzechy ludzi w opowieściach historycznych okresu Smuty, częściej niż w opowieściach wojennych, występowały tendencje do wiązania przyczyn polskiej interwencji z działalnością konkretnych osób bądź grup społecznych. W Opowieści Abrahama Palicyna o oblężeniu klasztoru Troicko-Sergijewskiego winą za zamęt i chaos w państwie obarczono Samozwańców, „fałszywych carów, [przez których - U. W.] cała Rosja straszliwie cierpi, (...) bo bogactwo ze wszystkich grodów dla nich odbierane bywa" (OP, 166). W Placzu o niewoli i ostatecznym zburzeniu państwa rosyjskiego za głównych winowajców upadku Moskwy (traktowanego jako sprawiedliwa kara za powszechne przewinienia) uznano wszystkich carów moskiewskich, nie czyniąc wyjątku nawet dla najbardziej idealizowanego przezXVII-wiecznych pisarzy Fiodora Iwanowicza. Natomiast

${ }^{5}$ Identyczny motyw kobicty występującej równoczcśnic w roli wdowy i narzeczonej pojawił sį̨ już w najstarszcj kronicc ruskicj, Pourieści minionych lat, w cpizodzic o zemstach księżnej Olgi, mszczącej się na Drewlanach za zabójstwo mє̨ża, ksiçcia Igora. Zob. Памятники литературы Древней Руси. XI-начало XII в., Москва 1987, s. 68-73. 
w Nowej opowieści o przesławnym carstwie rosyjskim winnymi niepowodzeń uczyniono przedstawicieli możnych rodów posiadaczy ziemskich, nazwanych „ziemiodzierżcami” (земледержчы), zaszyfrowując ocenę moralną ich czynów w trudnym do przetłumaczenia na język polski neologizmie „ziemiożercy” (землесъедиы). Oparty na podobieństwie semantycznym do wyrazu określanego, neologizm ten zawierał w sobie aluzję do charakterystycznej właściwości postępowania „ziemiodzierżców”, mianowicie zagarniania wszystkiego do siebie. Rywalizując między sobą o zaszczyty i stanowiska, kierując się

...pychą i nienawiścią wielu [z nich — U. W.] nie zechciało spośród chrześcijańskiego rodu cara wybrać i jemu służyć, a zamyśliło u innowierców i bezbożników cara poszukać i jemu służyć

$(\mathrm{NO}, 30)$.

Krytyczną ocenę działań ludzi decydujących o losach państwa wzmacniało dodatkowe określenie autorskie: „krzywdziciele” (кривители), zbudowane na wzór wcześniejszego neologizmu. Do jego utworzenia wykorzystano neutralne słowo „rządzący”, w przekładzie bardziej adekwatnym: „praworządcy” (правumeлu), zastępując jego rdzeń kojarzący się z prawdą rdzeniem o przeciwstawnym znaczeniu — „krzywda”. Zestawienie obu wyrazów w nierozerwalną parę: „rządzący krzywdziciele” (правители-кривители) przekształciło pojedyncze określenia w wyrazisty komentarz ujawniający stanowisko autora.

Równie negatywnie oceniano poczynania tych „ziemiodzierżców”, którzy dla osobistych korzyści „do rozbójnika króla całym sercem przystali i przeklęte dusze swoje zagubili i zatracili, i chcą jego, złoczyńcę, na (...) wielką dzierżawę posadzić, i jemu służyć” (NO, 30) i „o niego się troszczą i wszelkiego dobra mu życzą i wielkie carstwo Rosyjskie chcą mu oddać" (NO, 32). W opiniach autorów oceniających takie postawy pojawiały się zarówno emocjonalne epitety w funkcji charakteryzującej, typu: „nieludzie”, „nowi odstępcy”, „zdrajcy-jednowiercy”, „współbracia Judasza”, „kuzyni Szatana” i wiele innych, jak też bezpośrednio wyrażane sądy demaskujące motywy działań, odsłaniające upadek moralności czy oskarżające winnych, na przykład:

...a ci nikczemnicy nasi (...) zdeprawowani w umysłach swoich zapragnęli pokusom świata tego służyć i wielką sławę mieć (...) i nie wedle dostojeństwa swego zaszczytny tytuł zdobyć

$(\mathrm{NO}, 30)$;

...i rozum swój na zupełne szaleństwo zamienili, i do nich, wrogów, przyłączyli się, i przed nimi, jak przed swoim podnóżkiem na twarz upadli, i swoje pańskie pochodzenie zamienili na nędzne niewolnicze służenie

$(\mathrm{NO}, 46)$

...i tak to nasi szlachetnie urodzeni zgłupieli, i upadli duchem i przepadli na wieki

$(\mathrm{NO}, 46)$; 
...i jakby oślepli albo oniemieli, żaden nie ma odwagi temu wrogowi niczego zabronić i wielkiemu państwu w czymkolwiek dopomóc

$$
(\mathrm{NO}, 52) \text {. }
$$

Najgorszą sławą spośród zdrajców państwa rosyjskiego cieszyło się dwóch „sprzedawczyków” — bojarzyn Michał Sałtykow i szlachetka, „nie człowiek, a nie wiadomo kto” (NO, 50), Fied'ka Andronow. Pierwszego z nich, jednego z organizatorów podpalenia Moskwy podczas powstania ludności w marcu 1611 roku, uważano za niegodnego noszenia imienia swoich patronów Michała Archanioła oraz świętych Michała Kłopskiego i Michała Czernihowskiego. Drugiego porównywano do Piłata i Ichniłata ${ }^{6}$ i odbierano mu prawo do nazwiska kojarzącego się $z$ imieniem świętego Andrzeja. Z tego powodu w Nowej opowieści występował on pod nazwiskiem Afedronow, nawiązującym do greckich słów atheos 'bezbożnik' i athemitos - 'sprzeczny z prawem, bezprawny,7. Wyszydzano jego tytuł szlachecki otrzymany za zasługi dla Zygmunta III, ale głównie zarzucano mu działania wymierzone w podstawy państwa:

A on, przeklęty, (...) w jednej chwili albo krótkim czasie wszystko chce porozdawać, roztrwonić i zmarnować, i zostawić tę carską zakrystię całkowicie zniszczoną, jakby pusty i niepotrzebny dom. A nawet już zostawił! I teraz te ogromne bogactwa, drogocenne kamienie i stroje, i wszelkie rzeczy, o których nawet nie wiemy, i których nie widzimy razem ze wspólnikami swoimi grabi i przedmioty do przedmiotów dokłada, do tego złoto, srebro i perły w wielkie skrzynie sypie i temu (...) rozbójnikowi, wrogowi naszemu, królowi i złodziejowi pod ten broniący nas gród [Smoleńsk - U. W.] posyła

$$
\text { (NO, 52; por. tez: PN, 140). }
$$

Andronowowi i jemu podobnym przeciwstawiano dwóch bezkompromisowych działaczy państwowych — metropolitę Filareta i księcia Wasyla Golicyna, którzy —- pertraktując z Żółkiewskim stojącym pod murami Moskwy - doprowadzili w sierpniu 1610 roku do zawarcia nowego układu zobowiązującego przyszłego cara — królewicza Władysława do przestrzegania dotychczasowej supremacji prawosławia i niezmieniania istniejących praw i przywilejów. Znaleźli się następnie w składzie „wielkiego poselstwa moskiewskiego” wysłanego z Moskwy do obozu Zygmunta III pod Smoleńsk w celu wyjaśnienia pewnych nieścisłości układu, między innymi sprawy przyjęcia prawosławia przez Władysława i podpisania dwustronnych zobowiązań. Wzorem do naśladowania stała się ich nieprzekupna postawa w trakcie pertraktacji z Zygmuntem III planującym pozyskanie korony rosyjskiej dla siebie, w związku z czym niezainteresowanym zmianą wyznania przez syna, będącą dla Rosjan podstawowym warunkiem wyniesienia Władysława Wazy na tron.

\footnotetext{
${ }^{6}$ Imiç bohatera - przebicgłego intryganta z popularncj XV-wiccznej opowicści dydaktyczncj Stefanit $i$ Ichnilat, przełożonej z greckicgo oryginału. Został on stracony za oszukiwanie cara, któremu miał doradzać. Tekst utworu w: Памятники литературы Древней Руси. Конеч XV-перваяполовина XVI в. , Москва 1984, s. $152-221$.

7 Zob. А. В. Сальнова, Карманный новогреческо-русский словарь, Москва 1986, s. 20. Por. też znaczenia imion Андрей 'мужественный', 'храбрый' і Андрон 'муж победитель', w: А. Н. Тихонов, Л. 3. Бояринова, А. Г. Рыжкова, Словарь русских личных имен, Москва 1995, s. 45, 48.
} 
Dzięki ich uporowi wszelkie próby zmiany wynegocjowanego układu, a potem pozbycia się nazbyt kłopotliwego poselstwa zakończyły się niepowodzeniem. W przeciwieństwie do pozostałych delegatów, w tym Andronowa i Sałtykowa, którzy przyjęli dary i rozjechali się do domów, nie złożyli oni przysięgi na wierność Zygmuntowi i bronili porozumień zawartych w sierpniu aż do chwili aresztowania, wysłania do Polski i osadzenia na wiele lat w Malborku. Przedstawiani w utworach staroruskich jako odważni konspiratorzy, wysyłający z oblężonego Smoleńska tajne pisma $z$ informacjami o złamaniu warunków umowy i chęci pretendowania króla do korony rosyjskiej, dostarczali rodzącym się ruchom patriotycznym nie tylko cennych wiadomości, ale także przykładów osobistego męstwa.

Najbardziej wyidealizowanym przez pisarzy staroruskich uczestnikiem wojny polsko-rosyjskiej okazał się przywódca kształtującej się po śmierci Samozwańca II („tuszyńskiego łotra”) antypolskiej opozycji o charakterze religijno-narodowym — patriarcha Hermogenes. Jego rolę w podtrzymywaniu ducha narodu eksponowano w sposób szczególny. Przedstawiając go jako „dobrego pasterza” i „nauczyciela” (NO, 26, 32), „ojca ojców” (NO, 28), „silnego orędownika” (NO, 46) i „samotnego męża-olbrzyma” (NO, 34), a także jako symboliczny „mur i przyłbicę” (NO, 46) czy „niezłomny słup stojący pośrodku wielkiego państwa” (NO, 32), uczyniono zeń jedyną ostoję nadziei i wiary w zwycięstwo. Pouczano, iz wraz z jego śmiercią wiara ta „przez tych dzisiejszych naszych niszczycieli ostatecznie zgubiona zostanie, jeśli tylko nie okażemy im nienawiści" (NO, 46).

Agitowano więc za podjęciem sprzeciwu wobec interwentów, dając wskazówki bezpośrednie, w rodzaju: „Nie upadajcie na duchu, lecz uzbrajajcie się i uderzajcie na wrogów” (NO, 36); „Bądźcie mężni i uzbrajajcie się, i radźcie między sobą, jak by tu nas od wrogów oswobodzić” (NO, 46), albo też zachęcając do walki pośrednio - przez odsłanianie prawdziwych zamiarów króla i demaskowanie jego polityki wobec Rosji:

I nie wierzcie obłudzie, jaką przed wami czynią: sami ludzi swoich śmiercią karzą. A przez cały czas oszukują nas, przekonując i kusząc, że to wszystko robią i mówią po to, żeby nie ojca, a syna u nas mieć

$(\mathrm{NO}, 38)$

Król od dawna czekał na to, żeby ruskich ludzi oszukać, obiecał dać na carstwo syna swojego i posłał ludzi swoich do Moskwy, a gdy przyszli zawładnęli carstwem.

(PO, 158).

Propagowano również nową niespotykaną we wcześniejszych zabytkach metodę stawiania oporu, mianowicie udawanie lojalności i pogodzenia się z sytuacją, a w rzeczywistości postępowanie w myśl zasady „mówcie jedno, a róbcie drugie” (NO, 46). Sugerowano wreszcie, że tajni opozycjoniści mogą znajdować się wśród deklarujących poparcie dla Zygmunta III:

A tego nie wiadomo, czy wszyscy z potrzeby serca przystali do niego, czy w skrytości są nam wierni, choć teraz spokornieli, to razem z nami chcą wiary bronić, 
tylko rozeszli się i rozjechali, jedni do nas, drudzy — gdzie kto mieszka.

$(\mathrm{NO}, 82)$

Występujące zatem w staroruskich opowieściach historycznych elementy „realistyczności” pozwoliły autorom stworzyć wiarygodną iluzję rzeczywistości początku XVII stulecia, przedstawić wydarzenia zgodnie z ówczesną wiedzą na ich temat, odtworzyć atmosferę im towarzyszącą, urealnić przyczyny, motywy i siły sprawcze działań oraz wyrazić osobisty stosunek do nich. Pozwoliły także wskazać najważniejsze etapy wojny polsko-rosyjskiej, takie jak oblężenie Smoleńska i jego obrona dowodzona przez Michała Szeina, przełamanie przez Skopina-Szujskiego oblężenia klasztoru Troicko-Sergijewskiego, rokowania w sprawie objęcia tronu moskiewskiego przez Polaka, ukształtowanie się antypolskiej opozycji, uformowanie pospolitego ruszenia, wybuch powstania w Moskwie, kapitulacja garnizonu polskiego czy zawarcie rozejmu we wsi Deulino (Dywilino) w styczniu 1619 roku. 